11 Дослідження Г. Менша [Електронний ресурс] . - Режим доступу: http://www.managerhelp.org/hoks-1458-

1.html. - Назва 3 екрана.

12 Ефремов В. С. Бизнес - системы постиндустриального мира / В.С. Ефремов
// Менеджмент в России и за рубежом. 1999. - №5. - С. 15 .

13 Дикань В. Л. Розвиток промислового потенціалу українських підприємств / В. Л. Дикань // Вісник економіки транспорту і промисловості. 2014. - № 46. - C.136 - 142 .

\title{
КОНЦЕПЦІЯ ЖИТТЕВОГО ЦИКЛУ В ТЕОРЕТИЧНОМУ ПІДХОДІ ДО ВИБОРУ ВАРІАНТУ ІНВЕСТИЦІЙ В ОНОВЛЕННЯ ПАРКА ТЯГОВОГО РУХОМОГО СКЛАДУ
}

\author{
Калабухін Ю.С., о.т.н., професор, \\ Каменева Н.М, к.е.н., доцент, \\ Зленко Д.Д., магістр (УкрДУЗТ)
}

Проаналізовано проблеми, що виникають у зв'язку із реалізачією програми оновлення тягового рухомого складу локомотивного господарства залізниць України. Розглянуто теоретичні положення вибору варіанту оновлення тягового рухомого складу з урахуванням його жстттєвого ииклу. Визначено, щзо використання економічного показника вартість життєвого циклу є одним з основних критеріїв при виборі варіанту рішень інвестиційного характеру на довгостроковий період. Визначено, щзо запропонований науково-прикладний підхід слід покласти в основу техніко-економічного обтрунтування альтернативних варіантів інвестиційних рімень розвитку локомотивного господарства залізниць Украӥни.

Ключові слова: інвестицї, локомотивне господарство, тяговий рухомий склад, оновлення, вартість життевого циклу.

\section{КОНЦЕПЦИЯ ЖИЗНЕННОГО ЦИКЛА В ТЕОРЕТИЧЕСКОМ ПОДХОДЕ К ВЫБОРУ ВАРИАНТА ИНВЕСТИЦИЙ В ОБНОВЛЕНИЕ ТЯГОВОГО ПОДВИЖНОГО СОСТАВА}

\author{
Калабухин Ю.Е., д.m.н., профессор, \\ Каменева Н.Н., к.э.н., доцент, \\ Зленко Д.Д., магистр (УкрГУЖТ)
}

\begin{abstract}
Проанализированы проблемы, связанные с реализаџией программы обновления тягового подвижного состава локомотивного хозяйства железных дорог Украины. Рассмотрень теоретические положения выбора варианта обновления тягового подвижного состава с учетом его жизненного ичила. Определено, что использование экономического показателя стоимость жизненного ичила является одним из основных
\end{abstract}

(C) Калабухін Ю.С., Каменевева Н.М., Зленко Д.Д.
Вісник економіки транспорту і промисловості № 62, 2018 241 
критериев при выборе варианта решений инвестиционного характера на долгосрочный период. Определено, что предложенный научно-прикладной подход следует положить в основу технико-экономического обоснования альтернативных вариантов инвестициионных решений развития локомотивного хозяйства железных дорог Украиньл.

Ключевые слова: инвестиции, локомотивное хозяйство, тяговый подвижной состав, обновление, стоимость жизненного цикла.

\title{
CONCEPTION OF LIFE CYCLE IN THEORETICAL APPROACH TO CHOICE OF VARIANT OF INVESTMENTS IN UPDATE OF HAULING MOBILE COMPOSITION
}

\author{
Kalabukhin Y.E., Dr. techn. Sciences, \\ Kameneva N.N., Candidate of Economic Sciences, associate professor \\ Zlenko D.D., master's degree (USURT)
}

Updating of hauling rolling stock of railway transport can be realized both due to purchase of new technique and due to modernisation of existing one. In both cases it requires considerable capital investments, especially when purchase or modernisation options are examined with bringing in of foreign producers. In the conditions of limitation of investments a railway transport needs realization of engineering and economical analysis and scientific rationale for choosing of possible variants of new technique updating. Thus engineering and economical calculations must take into account the following stages: productions of progressive types of technique, its maintenance and utilization. These stages are the protracted period of time (30-40) during this period such changes are possible: in the national economy; volumes of transportations; cost indexes and normative base; indexes of the technical state (of reliability, economy, productivity, ecological safety of technical equipments).

Presently abroad for the estimation of efficiency of investment projects conception of life cycle cost (Product Life Cycle Cost - LCC) is widely used.

The problems related to the realization of the program of hauling rolling stock updating of locomotive economy of the Ukrainian railways are analysed in the article. Theoretical positions of choice of variant of hauling rolling stock updating are considered taking into account its life cycle. It is defined that the use of economic indicator of life cycle cost is one of basic criteria at the choice of variant of decisions of investment character on a long-term period. It is defined that proposed scientifically-applied approach is necessary to take as a basis of feasability study of alternative variants of investment decisions of locomotive economy development of the Ukrainian railways.

Key words: investment, locomotive economy, traction rolling stock, upgrading, life cycle costs.

Постановка проблеми. Віковий та технічний стан існуючого тягового рухомого складу залізниць України вимагає скорішого його оновлення. Це можливо як за рахунок його модернізації, так і за рахунок придбання нових зразків вітчизняного або зарубіжного виробництва. Це знайшло своє відображення в «Комплексній програмі оновлення залізничного рухомого складу України на 2008-2020 роки», яка введена в дію наказом Міністерства транспорту i зв'язку від 14 жовтня 2008 р. №1259 [1].

Розробка, освоєння виробництва i придбання сучасного тягового рухомого складу потребує проведення техніко- 
економічного аналізу i наукового обгрунтовування вибору можливих варіантів оновлення нової техніки.

Аналіз останніх досліджень i публікацій. На теперішній час невід'ємним компонентом економічних відносин на ринках промислової продукції між виробниками та замовниками залізничної техніки стає взаємодія в рамках концепції вартості життєвого циклу (LCC).

Розвиток ринкових відносин ставить перед залізницями задачу більш широкого використання цього економічного показника як одного 3 основних критеріїв при оцінках i ухваленні рішень інвестиційного характеру на довгостроковий період. Основні положення життєвого циклу, оцінки його вартості стосовно до тягового рухомого складу розглянуто в роботах Іванової Н.Г., Павлова Л.М., Тартаковського Е.Д., Грищенко С.Г., Фалендиша А.П. та ін. [2-10].

Невирішені питання у загальній темі дослідження. Необхідність інвестиційного забезпечення розвитку локомотивного господарства залізниць України охоплює оновлення широкого спектру тягового рухомого складу як за видами тяги, так i за видами експлуатаційної роботи, що ним планується виконувати. Незважаючи на значну кількість результатів дослідження стосовно використання економічного показника LCC як одного 3 основних критеріїв при оцінках і ухваленні рішень інвестиційного характеру на довгостроковий період, питання адаптації цього показника до експлуатаційних особливостей залізниць України потребує подальшого розвитку.

Мета статті. Метою статті $\epsilon$ виклад теоретичних положень вибору варіанту інвестицій в оновлення парку тягового рухомого складу з урахуванням життєвого циклу.

Виклад основного матеріалу дослідження. Вартість життєвого циклу парку тягового рухомого складу за альтернативним варіантом інвестицій в його оновлення визначається за формулами:

$$
\begin{aligned}
& \mathrm{LCC}_{1}=\sum_{\mathrm{t}=\mathrm{t}_{\Pi_{1}}}^{\mathrm{t}=\mathrm{t}_{\mathrm{K} 1}}\left(\mathrm{~m}_{1_{\mathrm{t}}} \cdot Ц_{1_{\mathrm{t}}}^{\mathrm{\Pi}} \cdot \alpha_{\mathrm{t}}\right)+\sum_{\mathrm{t}=\mathrm{t}_{\Pi_{1}}}^{\mathrm{t}=\mathrm{t}_{\mathrm{K}}}\left(\mathrm{K}_{1_{\mathrm{t}}}^{\mathrm{cy \Pi}} \cdot \alpha_{\mathrm{t}}\right)+\sum_{\mathrm{t}=\mathrm{t}_{\Pi_{1}}}^{\mathrm{t}=\mathrm{t}_{\mathrm{K} 1}}\left(\mathrm{~m}_{1_{\mathrm{t}}} \cdot \bigsqcup_{1_{\mathrm{t}}}^{\mathrm{KP}} \cdot \alpha_{\mathrm{t}}\right)+ \\
& +\sum_{\mathrm{t}=\mathrm{t}_{\Pi_{1}}}^{\mathrm{t}=\mathrm{t}_{\mathrm{K}}}\left(\mathrm{m}_{1_{\mathrm{t}}} \cdot Ц_{1_{\mathrm{t}}}^{\mathrm{m}} \cdot \alpha_{\mathrm{t}}\right)+\sum_{\mathrm{t}=\mathrm{t}_{\Pi_{1}}}^{\mathrm{t}=\mathrm{t}_{\mathrm{K} 1}}\left(\mathrm{~m}_{1_{\mathrm{t}}} \cdot{\Lambda_{1}}_{1_{\mathrm{t}}} \cdot \alpha_{\mathrm{t}}\right)-\sum_{\mathrm{t}=\mathrm{t}_{\mathrm{t}_{1}}}^{\mathrm{t}=\mathrm{t}_{\mathrm{K} 1}}\left(\mathrm{~m}_{1_{\mathrm{t}}} \cdot \pi_{1_{\mathrm{t}}} \cdot \alpha_{\mathrm{t}}\right) \\
& \mathrm{LCC}_{2}=\sum_{\mathrm{t}=\mathrm{t}_{\Pi_{2}}}^{\mathrm{t}=\mathrm{t}_{\mathrm{K} 2}}\left(\mathrm{~m}_{2_{\mathrm{t}}} \cdot Ц_{2_{\mathrm{t}}}^{\mathrm{\Pi}} \cdot \alpha_{\mathrm{t}}\right)+\sum_{\mathrm{t}=\mathrm{t}_{\Pi_{2}}}^{\mathrm{t}=\mathrm{t}_{\mathrm{K} 2}}\left(\mathrm{~K}_{2_{\mathrm{t}}}^{\mathrm{cy \Pi}} \cdot \alpha_{\mathrm{t}}\right)+\sum_{\mathrm{t}=\mathrm{t}_{\Pi_{2}}}^{\mathrm{t}=\mathrm{t}_{\mathrm{K} 2}}\left(\mathrm{~m}_{2_{\mathrm{t}}} \cdot \bigsqcup_{2_{\mathrm{t}}}^{\mathrm{KP}} \cdot \alpha_{\mathrm{t}}\right)+ \\
& +\sum_{t=t_{\Pi 2}}^{t=t_{K 2}}\left(m_{2_{t}} \cdot Ц_{2_{t}}^{\mathrm{M}} \cdot \alpha_{t}\right)+\sum_{t=t_{\Pi 2}}^{t=t_{K 2}}\left(m_{2_{t}} \cdot h_{2_{t}} \cdot \alpha_{t}\right)-\sum_{t=t_{\Pi 2}}^{t=t_{K 2}}\left(m_{2_{t}} \cdot \pi_{2_{t}} \cdot \alpha_{t}\right)
\end{aligned}
$$

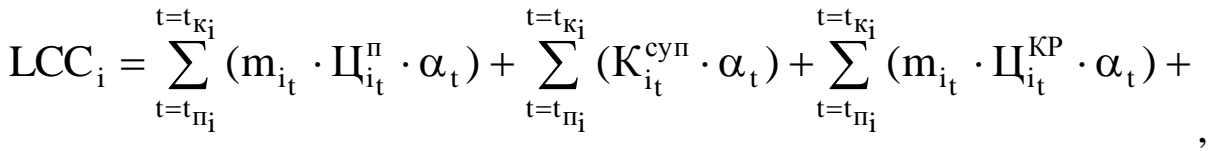

$$
\begin{aligned}
& +\sum_{t=t_{\Pi_{i}}}^{t=t_{K_{i}}}\left(m_{i_{t}} \cdot \bigsqcup_{i_{t}}^{M} \cdot \alpha_{t}\right)+\sum_{t=t_{\Pi_{i}}}^{t=t_{K_{i}}}\left(m_{i_{t}} \cdot U_{i_{t}} \cdot \alpha_{t}\right)-\sum_{t=t_{\Pi_{i}}}^{t=t_{K_{i}}}\left(m_{i_{t}} \cdot \pi_{i_{t}} \cdot \alpha_{t}\right)
\end{aligned}
$$


де $\mathrm{m}_{1_{\mathrm{t}}}, \mathrm{m}_{2_{\mathrm{t}}}, \mathrm{m}_{\mathrm{i}_{\mathrm{t}}}-$ кількість одиниць тягового рухомого складу відповідно, за 1, 2..і-им варіантом інвестицій, яку придбано в рік $\mathrm{t}$ життєвого циклу;

$$
\bigsqcup_{1_{t}}^{\Pi}, \bigsqcup_{2_{t}}^{\Pi}, Ц_{i_{t}}^{\Pi}-\text { ціна придбання }
$$

одиниці тягового рухомого складу відповідно, за 1, 2...і-им варіантом інвестицій в рік $\mathrm{t}$ життєвого циклу, грн.;

$$
\mathrm{K}_{1_{\mathrm{t}}}^{\text {суп }}, \mathrm{K}_{2_{\mathrm{t}}}^{\text {суп }}, \mathrm{K}_{\mathrm{i}_{\mathrm{t}}}^{\text {суп }}-\text { одноразові }
$$

супутні витрати при втілені парку тягового рухомого складу відповідно, за 1 , 2...і-им варіантом інвестицій в рік $\mathrm{t}$ життєвого циклу, грн.;

$$
\bigsqcup_{1_{t}}^{\mathrm{KP}}, \quad \bigsqcup_{2_{t}}^{\mathrm{KP}}, \quad \bigsqcup_{i_{\mathrm{t}}}^{\mathrm{KP}} \quad-\text { ціна }
$$

капітального ремонту одиниці тягового рухомого складу відповідно, за $1,2 \ldots$ i-им варіантом інвестицій в рік $\mathrm{t}$ життєвого циклу, грн.;

$$
\bigsqcup_{1_{t}}^{\mathrm{M}}, Ц_{2_{\mathrm{t}}}^{\mathrm{M}}, \bigsqcup_{\mathrm{i}_{\mathrm{t}}}^{\mathrm{M}}-\text { ціна модернізації }
$$

одиниці тягового рухомого складу відповідно, за 1, 2...і-им варіантом інвестицій в рік $\mathrm{t}$ життєвого циклу, грн.;

$$
И_{1_{\mathrm{t}}}, И_{2_{\mathrm{t}}}, И_{\mathrm{i}_{\mathrm{t}}}-\text { поточні витрати }
$$

на експлуатацію та утримання в технічно справному стані парку тягового рухомого складу відповідно, за 1, 2...і-им варіантом інвестицій в рік $\mathrm{t}$ життєвого циклу, грн.;

$\pi_{1_{\mathrm{t}}}, \quad \Omega_{2_{\mathrm{t}}}, \quad \pi_{\mathrm{i}_{\mathrm{t}}}-$ ліквідаційна вартість одиниці тягового рухомого складу відповідно, за 1, 2...і-им варіантом інвестицій в рік $\mathrm{t}$ життєвого циклу, грн.;

$\alpha_{t}-$ коефіцієнт дисконтування;

$\mathrm{t}_{\Pi_{1}}, \mathrm{t}_{\Pi_{2}}, \mathrm{t}_{\Pi_{i}}-$ рік придбання парку тягового рухомого складу відповідно, за 1, 2...і-им варіантом інвестицій;

$$
\mathrm{t}_{\kappa_{1}}, \mathrm{t}_{\kappa_{2}}, \mathrm{t}_{\kappa_{i}}-\text { рік ліквідації парку }
$$

тягового рухомого складу відповідно, за 1 , 2...і-им варіантом інвестицій.

Очевидно перший доданок $\mathrm{y}$ формулах (1)-(3) уявляє собою інвестиції залізниць України в оновлення парку тягового рухомого складу за варіантом, другий доданок - супутні витрати на втілення парку тягового рухомого складу за варіантом інвестицій (в залежності від умов придбання можуть бути віднесені до етапу придбання або експлуатації), третій доданок - витрати на капітальні ремонти парку тягового рухомого складу за варіантом інвестицій, четвертий доданок витрати на модернізацію парку тягового рухомого складу за варіантом інвестицій, п'ятий доданок - поточні витрати на експлуатацію та утримання в технічно справному стані парку тягового рухомого складу за варіантом інвестицій, шостий доданок - ліквідаційну вартість парку тягового рухомого складу за варіантом інвестицій.

$$
\begin{aligned}
& \text { Позначимо: } \\
& \sum_{t_{\Pi о ч}}^{t_{K}} K_{\Pi_{i}}^{I}=\sum_{t=t_{\Pi_{i}}}^{t=t_{K_{i}}}\left(m_{i_{t}} \cdot Ц_{i_{t}}^{\Pi} \cdot \alpha_{t}\right) \text {, } \\
& \sum_{t_{\text {поч }}}^{t_{K}} K_{\text {суп }}^{I / I I}=\sum_{t=t_{\Pi_{i}}}^{t=t_{K_{i}}}\left(K_{i_{t}}^{c y \Pi} \cdot \alpha_{t}\right), \\
& \sum_{t_{\Pi о ч}}^{t_{K}} K_{K P_{i}}^{I I}=\sum_{t=t_{\Pi_{i}}}^{t=t_{K_{i}}}\left(m_{i_{t}} \cdot Ц_{i_{t}}^{K P} \cdot \alpha_{t}\right) \text {, } \\
& \sum_{t_{\Pi о ч}}^{t_{K}} K_{M_{i}}^{I I}=\sum_{t=t_{\Pi_{i}}}^{t=t_{K_{i}}}\left(m_{i_{t}} \cdot \coprod_{i_{t}}^{\mathrm{M}} \cdot \alpha_{t}\right) \text {, } \\
& \sum_{t_{\Pi о ч}}^{t_{K}} U_{i}^{I I}=\sum_{t=t_{\Pi_{i}}}^{t=t_{K_{i}}}\left(m_{i_{t}} \cdot h_{i_{t}} \cdot \alpha_{t}\right) \text {, } \\
& \sum_{\mathrm{t}_{\text {Поч }}}^{\mathrm{t}_{\mathrm{K}}} \pi_{\mathrm{i}}^{\mathrm{III}}=\sum_{\mathrm{t}=\mathrm{t}_{\Pi_{\mathrm{i}}}}^{\mathrm{t}=\mathrm{t}_{\mathrm{K}_{\mathrm{i}}}}\left(\mathrm{m}_{\mathrm{i}_{\mathrm{t}}} \cdot{\boldsymbol{I}_{\mathrm{i}_{\mathrm{t}}}}_{\mathrm{t}_{\mathrm{t}}} \cdot \alpha_{\mathrm{t}}\right) \text {. }
\end{aligned}
$$$$
\text { де I - етап придбання парку }
$$

тягового рухомого складу залізницями України за і-им варіантом інвестицій;

II - етап експлуатації парку тягового рухомого складу залізницями України за і-им варіантом інвестицій;

III - етап ліквідації парку тягового рухомого складу залізниць України за і-им варіантом інвестицій.

$$
3 \text { урахуванням виразів (5)-(10) }
$$

формула (4) приймає вид 


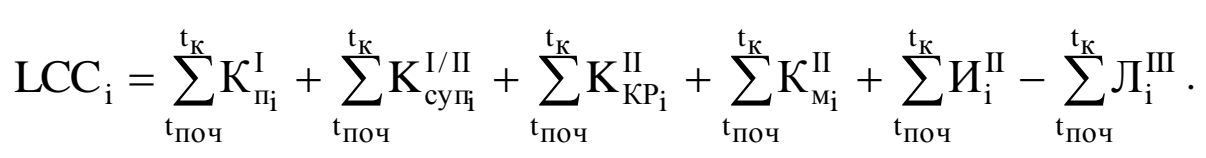

де $\mathrm{t}_{\text {поч }}$ - рік початку експлуатації парку тягового рухомого складу.

Вартість життєвого циклу відображає лише абсолютні витрати користувача нової техніки на піi експлуатацію та утримання в технічно справному стані. Тому для більш повного аналізу доцільності інвестицій цей показник слід доповнити відносними показниками ефективності використання матеріальних ресурсів, енергоресурсів, робочої сили, екологічної безпеки та соціальної ефективності від застосування парку нового тягового рухомого складу.

Середньо-експлуатаційна ефективність і-го варіанту інвестицій в оновлення парку тягового рухомого складу визначається за формулою

$$
\begin{gathered}
\overline{\mathrm{E}} \phi_{\mathrm{i}}=\frac{\sum_{\mathrm{t}_{\text {поч }}}^{\mathrm{t}_{\mathrm{K}}} \mathrm{Q}_{\mathrm{i}}^{\mathrm{II}}}{\mathrm{LCC}_{\mathrm{i}}}, \\
\text { де } \sum_{\mathrm{t}_{\text {поч }}}^{\mathrm{t}_{\mathrm{K}}} \mathrm{Q}_{\mathrm{i}}^{\mathrm{II}}-\text { обсяг експлуатаційної }
\end{gathered}
$$

роботи (ОЕР), який виконано парком нового тягового рухомого складу за життєвий цикл за і-им варіантом інвестицій, ОЕР.

\section{Середньо-експлуатаційна}

ефективність використання всіх видів ресурсів для роботи парку нового тягового рухомого складу за і-им варіантом інвестицій визначається за формулою

$$
\bar{C}_{i}=\frac{L C_{i}}{\sum_{t_{\text {Поч }}}^{t_{K}} Q_{i}^{I I}}
$$

Середньо-експлуатаційна енергоємність парку нового тягового рухомого складу за і-им варіантом інвестицій визначається за формулою

$$
\begin{gathered}
\overline{\mathrm{E}}_{\mathrm{i}}=\frac{\sum_{\mathrm{t}_{\text {поч }}}^{\mathrm{t}_{\mathrm{K}}} \mathrm{E}_{\mathrm{i}}^{\mathrm{II}}}{\sum_{\mathrm{t}_{\text {поч }}}^{t_{K}} \mathrm{Q}_{\mathrm{i}}^{\mathrm{II}}}, \\
\sum_{\mathrm{t}_{\text {поч }}}^{\mathrm{t}_{\mathrm{K}}} \mathrm{E}_{\mathrm{i}}^{\mathrm{II}}-\text { енергоспоживання }
\end{gathered}
$$

парку нового тягового рухомого складу за життєвий цикл за і-им варіантом інвестицій, кг(кВт-год).

Середньо-експлуатаційний

виробіток при застосуванні парку нового тягового рухомого складу за і-им варіантом інвестицій визначається за формулою

$$
\begin{gathered}
\overline{\mathrm{H}}_{\mathrm{i}}=\frac{\sum_{\mathrm{t}_{\text {поч }}}^{\mathrm{t}_{\mathrm{K}}} \mathrm{Q}_{\mathrm{i}}^{\mathrm{II}}}{\sum_{\mathrm{t}_{\mathrm{K}}}^{\mathrm{t}_{\text {поч }}} \mathrm{L}_{\mathrm{i}}^{\mathrm{II}}}, \\
\text { де } \quad \sum_{\mathrm{t}_{\text {поч }}}^{\mathrm{t}_{\mathrm{K}}} \mathrm{L}_{\mathrm{i}}^{\mathrm{II}}-
\end{gathered}
$$

експлуатації та утримання парку нового тягового рухомого складу в технічно справному стані за життєвий цикл за і-им варіантом інвестицій, чол-год.

Середньо-експлуатаційна

матеріаломісткість парку нового тягового рухомого складу за і-им варіантом інвестицій визначається за формулою

$$
\bar{M}_{i}=\frac{\sum_{t_{\Pi о ч}}^{t_{K}} M_{i}^{I I}}{\sum_{t_{\Pi ० ч}}^{t_{K}} Q_{i}^{I I}},
$$

$$
\text { де } \sum_{\mathrm{t}_{\text {поч }}}^{\mathrm{t}_{\mathrm{K}}} \mathrm{M}_{\mathrm{i}}^{\mathrm{II}}-\text { матеріаломісткість }
$$

експлуатації парку нового тягового рухомого складу за життєвий цикл за і-им варіантом інвестицій, грн. 
Середньо-експлуатаційна маса викидів шкідливих речовин парком нових тепловозів та дизель-поїздів за і-им варіантом інвестицій визначається за формулою

$$
\begin{gathered}
\overline{\mathrm{W}}_{\mathrm{i}}=\frac{\sum_{\mathrm{t}_{\text {поч }}}^{\mathrm{t}_{\mathrm{K}}} \mathrm{W}_{\mathrm{i}}^{\mathrm{II}}}{\sum_{\mathrm{t}_{\text {поч }}}^{\mathrm{t}_{\mathrm{K}}} \mathrm{Q}_{\mathrm{i}}^{\mathrm{II}}}, \\
\text { де } \quad \sum_{\mathrm{t}_{\text {поч }}}^{\mathrm{t}_{\mathrm{K}}} \mathrm{W}_{\mathrm{i}}^{\mathrm{II}}-\text { маса викидів }
\end{gathered}
$$

шкідливих речовин парком нових тепловозів та дизель-поїздів за життєвий цикл за і-им варіантом інвестицій, кг.

Середньо-експлуатаційна екологічна безпека парку нових тепловозів та дизель-поїздів за і-им варіантом інвестицій визначається за формулою

$$
\bar{y}_{i}=\frac{\sum_{t_{\text {Поч }}}^{t_{K}} y_{i}^{I I}}{\sum_{t_{\text {поч }}}^{t_{K}} Q_{i}^{I I}},
$$

$$
\text { де } \sum_{\mathrm{t}_{\text {поч }}}^{\mathrm{t}_{\mathrm{K}}} \mathrm{y}_{\mathrm{i}}^{\mathrm{II}}-\text { оцінка шкоди, яка }
$$

наноситься навколишньому середовищу від експлуатації парку нових тепловозів та дизель-поїздів за життєвий цикл за і-им варіантом інвестицій, грн.

Середньо-експлуатаційна соціальна ефективність за і-им варіантом інвестицій в оновлення парку тягового рухомого складу визначається за формулою

$$
\begin{aligned}
& \overline{\mathrm{Ce}_{\mathrm{i}}}=\frac{\sum_{\mathrm{t}_{\Pi о ч}}^{\mathrm{t}_{\mathrm{K}}} \mathrm{Ce}_{\mathrm{i}}^{\mathrm{II}}}{\mathrm{LCC}_{\mathrm{i}}}, \\
& \text { де } \quad \sum_{\mathrm{t}_{\text {поч }}}^{\mathrm{t}_{\mathrm{K}}} \mathrm{Ce}_{\mathrm{i}}^{\mathrm{II}}-\text { соціальна }
\end{aligned}
$$

ефективність за і-им варіантом інвестицій в оновлення парку тягового рухомого складу за життєвий цикл, грн.

Вищенаведені показники життєвого циклу та критерії доцільності

\begin{tabular}{|c|c|c|c|c|}
\hline \multirow[t]{2}{*}{ Найменування показника } & \multicolumn{3}{|c|}{$\begin{array}{l}\text { Значення за варіантом } \\
\text { інвестицій в оновлення }\end{array}$} & \multirow{2}{*}{$\begin{array}{l}\text { Критерій } \\
\text { вибору }\end{array}$} \\
\hline & 1 & 2 & $\mathrm{i}$ & \\
\hline 1 & 2 & 3 & 4 & 5 \\
\hline Тривалість життєвого циклу, роки & $\mathrm{T}_{1}$ & $\mathrm{~T}_{2}$ & $\mathrm{~T}_{\mathrm{i}}$ & - \\
\hline $\begin{array}{l}\text { Обсяг експлуатаційної роботи, який } \\
\text { виконано парком ТРС за життєвий } \\
\text { цикл }\end{array}$ & $\sum_{\mathrm{t}_{\text {ПОч }}}^{\mathrm{t}_{\mathrm{K}}} \mathrm{Q}_{1}^{\mathrm{II}}$ & $\sum_{\mathrm{t}_{\text {ПОч }}}^{\mathrm{t}_{\mathrm{K}}} \mathrm{Q}_{2}^{\mathrm{II}}$ & $\sum_{\mathrm{t}_{\text {ПОч }}^{\mathrm{t}}}^{\mathrm{t}_{\mathrm{K}}} \mathrm{Q}_{\mathrm{i}}^{\mathrm{II}}$ & - \\
\hline Парк ТРС & $\mathrm{m}_{1_{\mathrm{t}}}$ & $\mathrm{m}_{2_{\mathrm{t}}}$ & $\mathrm{m}_{\mathrm{i}_{\mathrm{t}}}$ & - \\
\hline $\begin{array}{l}\text { Ціна придбання одиниці ТРС в рік t } \\
\text { життєвого циклу, грн. }\end{array}$ & $\bigsqcup_{1_{t}}^{\Pi}$ & $\bigsqcup_{2_{\mathrm{t}}}^{\mathrm{\Pi}}$ & $\bigsqcup_{i_{t}}^{\Pi}$ & - \\
\hline $\begin{array}{l}\text { Інвестиції в оновлення парку ТРС за } \\
\text { життєвий цикл, грн. }\end{array}$ & $\sum_{t_{\Pi о ч}}^{t_{K}} K_{\Pi_{1}}^{I}$ & $\sum_{t_{\Pi о ч}}^{t_{K}} K_{\Pi 2}^{I}$ & $\sum_{t_{\Pi о ч}}^{t_{K}} K_{\Pi_{i}}^{I}$ & - \\
\hline $\begin{array}{l}\text { Супутні витрати на втілення парку } \\
\text { ТРС за життєвий цикл, грн. }\end{array}$ & $\sum_{\mathrm{t}_{\text {поч }}}^{\mathrm{t}_{\mathrm{K}}} \mathrm{K}_{\text {суп }}^{\mathrm{I} / \mathrm{II}}$ & $\sum_{\mathrm{t}_{\text {поч }}}^{\mathrm{t}_{\mathrm{K}}} \mathrm{K}_{\text {суп }}^{\mathrm{I} / \mathrm{II}}$ & $\sum_{\mathrm{t}_{\text {Поч }}}^{\mathrm{t}_{\mathrm{K}}} \mathrm{K}_{\text {суп }}^{\mathrm{I} / \mathrm{II}}$ & - \\
\hline $\begin{array}{l}\text { Ціна капітального ремонту одиниці } \\
\text { ТРС в рік t життєвого циклу, грн. }\end{array}$ & $\bigsqcup_{1_{t}}^{K P}$ & $\coprod_{2 \mathrm{t}}^{\mathrm{KP}}$ & $\bigsqcup_{i_{t}}^{K P}$ & - \\
\hline
\end{tabular}
альтернативних варіантів інвестицій в оновлення парку тягового рухомого складу зведемо до таблиці 1.

Таблиия 1

Показники життєвого ичиклу інвестищій в оновлення парку тягового рухомого складу 
Продовження табл. 1

\begin{tabular}{|c|c|c|c|c|}
\hline 1 & 2 & 3 & 4 & 5 \\
\hline $\begin{array}{l}\text { Витрати на капітальні ремонти парку } \\
\text { ТРС за життєвий цикл, грн. }\end{array}$ & $\sum_{\mathrm{t}_{\Pi о ч}}^{\mathrm{t}_{\mathrm{K}}} \mathrm{K}_{\mathrm{KP}_{1}}^{\mathrm{II}}$ & $\sum_{t_{\text {ПОч }}}^{t_{K}} K_{K_{2}}^{I I}$ & $\sum_{\mathrm{t}_{\Pi О ч}}^{\mathrm{t}_{\mathrm{K}}} \mathrm{K}_{\mathrm{KP}_{\mathrm{i}}}^{\mathrm{II}}$ & - \\
\hline $\begin{array}{l}\text { Ціна модернізації одиниці ТРС в рік t } \\
\text { життєвого циклу, грн. }\end{array}$ & $\bigsqcup_{1_{\mathrm{t}}}^{\mathrm{M}}$ & $\bigsqcup_{2_{\mathrm{t}}}^{\mathrm{M}}$ & $\bigsqcup_{i_{t}}^{\mathrm{M}}$ & - \\
\hline $\begin{array}{l}\text { Витрати на модернізацію парку ТРС за } \\
\text { життєвий цикл, грн. }\end{array}$ & $\sum_{t_{\text {поч }}}^{t_{K}} K_{M_{1}}^{I I}$ & $\sum_{\mathrm{t}_{\text {Поч }}}^{\mathrm{t}_{\mathrm{K}}} \mathrm{K}_{\mathrm{M}_{2}}^{\mathrm{II}}$ & $\sum_{t_{\text {поч }}}^{t_{K}} K_{M_{i}}^{I I}$ & - \\
\hline $\begin{array}{l}\text { Поточні витрати на експлуатацію та } \\
\text { утримання в технічно справному стані } \\
\text { парку ТРС за життєвий цикл, грн. }\end{array}$ & $\sum_{\mathrm{t}_{\text {поч }}}^{\mathrm{t}_{\mathrm{K}}} \Pi_{1}^{\mathrm{II}}$ & $\sum_{\mathrm{t}_{\text {поч }}}^{\mathrm{t}_{\mathrm{K}}} \Pi_{2}^{\mathrm{II}}$ & $\sum_{\mathrm{t}_{\Pi о ч}}^{\mathrm{t}_{K}} U_{\mathrm{i}}^{\mathrm{II}}$ & - \\
\hline $\begin{array}{l}\text { Ліквідаційна вартість парку ТРС за } \\
\text { життєвий цикл, грн. }\end{array}$ & $\sum_{t_{\text {поч }}}^{\mathrm{t}_{\mathrm{K}}} \pi_{1}^{\mathrm{III}}$ & $\sum_{\mathrm{t}_{\text {поч }}}^{\mathrm{t}_{\mathrm{K}}} \boldsymbol{J}_{2}^{\mathrm{III}}$ & $\sum_{t_{\text {поч }}}^{t_{K}} \pi_{i}^{I I I}$ & - \\
\hline $\begin{array}{l}\text { Вартість життєвого циклу парку ТРС, } \\
\text { грн. }\end{array}$ & $\mathrm{LCC}_{1}$ & $\mathrm{LCC}_{2}$ & $\mathrm{LCC}_{\mathrm{i}}$ & $\mathrm{LCC}_{\mathrm{n}} \rightarrow \min$ \\
\hline $\begin{array}{l}\text { Середньо-експлуатаційна } \\
\text { ефективність інвестицій в оновлення } \\
\text { парку ТРС, ОЕР/грн. }\end{array}$ & $\overline{\mathrm{E}} \phi_{1}$ & $\overline{\mathrm{E}} \phi_{2}$ & $\overline{\mathrm{E}} \phi_{\mathrm{i}}$ & $\underset{\mathrm{E}}{\overline{\mathrm{E}} \phi_{\mathrm{n}} \rightarrow \mathrm{ma}}$ \\
\hline $\begin{array}{l}\text { Середньо-експлуатаційна } \\
\text { ефективність використання всіх видів } \\
\text { ресурсів для роботи парку ТРС, } \\
\text { грн./ОЕР }\end{array}$ & $\overline{\mathrm{C}}_{1}$ & $\overline{\mathrm{C}}_{2}$ & $\overline{\mathrm{C}}_{\mathrm{i}}$ & $\overline{\mathrm{C}}_{\mathrm{n}} \rightarrow \min$ \\
\hline $\begin{array}{l}\text { Середньо-експлуатаційна } \\
\text { енергоємність парку ТРС, кг (кВт- } \\
\text { год)/OЕР }\end{array}$ & $\overline{\mathrm{E}}_{1}$ & $\overline{\mathrm{E}}_{2}$ & $\overline{\mathrm{E}}_{\mathrm{i}}$ & $\overline{\mathrm{E}}_{\mathrm{n}} \rightarrow \min$ \\
\hline $\begin{array}{l}\text { Середньо-експлуатаційний виробіток } \\
\text { парку ТРС, ОЕР/чол-год }\end{array}$ & $\overline{\mathrm{H}}_{1}$ & $\overline{\mathrm{H}}_{2}$ & $\overline{\mathrm{H}}_{\mathrm{i}}$ & $\overline{\mathrm{H}}_{\mathrm{n}} \rightarrow \max$ \\
\hline $\begin{array}{l}\text { Середньо-експлуатаційна } \\
\text { матеріаломісткість парку ТРС, } \\
\text { грн./OЕР }\end{array}$ & $\overline{\mathrm{M}}_{1}$ & $\overline{\mathrm{M}}_{2}$ & $\overline{\mathrm{M}}_{\mathrm{i}}$ & $\overline{\mathrm{M}}_{\mathrm{n}} \rightarrow \min$ \\
\hline $\begin{array}{l}\text { Середньо-експлуатаційна маса викидів } \\
\text { шкідливих речовин тепловозами та } \\
\text { дизель-поїздами, кг/ОЕР }\end{array}$ & $\overline{\mathrm{W}}_{1}$ & $\overline{\mathrm{W}}_{2}$ & $\overline{\mathrm{W}}_{\mathrm{i}}$ & $\overline{\mathrm{W}}_{\mathrm{n}} \rightarrow \min$ \\
\hline $\begin{array}{l}\text { Середньо-експлуатаційна екологічна } \\
\text { безпека тепловозів та дизель-поїздів, } \\
\text { грн./OЕР }\end{array}$ & $\overline{\mathrm{y}}_{1}$ & $\overline{\mathrm{Y}}_{2}$ & $\overline{\mathrm{y}}_{\mathrm{i}}$ & $\overline{\mathrm{y}}_{\mathrm{n}} \rightarrow \min$ \\
\hline $\begin{array}{l}\text { Середньо-експлуатаційна соціальна } \\
\text { ефективність, грн./грн. }\end{array}$ & $\overline{\mathrm{C}} \mathrm{e}_{1}$ & $\overline{\mathrm{C}} \mathrm{e}_{2}$ & $\overline{\mathrm{C}} \mathrm{e}_{\mathrm{i}}$ & $\overline{\mathrm{C}} \mathrm{e}_{\mathrm{n}} \rightarrow \max$ \\
\hline
\end{tabular}

Висновки. Таким чином, в умовах ринкових відносин і обмеження інвестицій проблема вибору варіантів оновлення тягового рухомого складу залізниць України висувається на рівень проблем державного значення, рішення якої безпосередньо впливає на забезпечення національної безпеки i вимагає системного, програмного підходу шляхом проведення злагодженої політики між ученими, виробниками експлуатаційниками. В основу аналізу i 
регулювання аспектів економічної ефективності варіантів оновлення тягового рухомого складу, починаючи від його розробки, реалізації і використання, закінчуючи утилізацією, повинна бути покладена концепція вартості життєвого циклу.

\section{ПЕРЕЛІК ВИКОРИСТАНИХ ДЖЕРЕЛ}

1. Комплексна

програма оновлення залізничного рухомого складу України на 2008-2020 роки : Наказ Міністерства транспорту та зв'язку України від 14 жовтня 2008 року № 1259.

2. Павлов Л.Н. Концепция стоимости жизненного цикла как инструмент взаимодействия поставщиков и потребителей в условиях рыночной экономики в Европе / Л.Н. Павлов // Железнодорожный транспорт. - 2006. - № 9. - С. 75-77.

3. Иванова Н.Г. Применение методики расчета стоимости жизненного цикла при оценке эффективности инноваций на железнодорожном транспорте / Н.Г. Иванова // Локомотивинформ. - 2007. - № 8. - С. 12-15.

4. Иванова Н.Г. Применение показателя стоимости жизненного цикла при оценке эффективности новых локомотивов / Н.Г. Иванова // Бюллетень транспортной информации. - 2007. - № 1. - C. 21-25.

5. Калабухін Ю.С. Теоретичні положення визначення вартості життєвого циклу тягового рухомого складу / Ю.Є.
Калабухін // Вісник Дніпропетровського національного університету залізничного транспорту ім. ак. В. Лазаряна, 2008. Вип. 24. - С. 221-225.

6. Калабухін Ю.С. Теоретичні положення оновлення тягового рухомого складу з урахуванням життєвого циклу / Ю.Є. Калабухін, Е.Д. Тартаковський // Зб. наукових праць. - Х. : УкрДАЗТ. - 2009. Вип. 111. - С. 106-120.

7. Мирошниченко P.В. Экономическая оценка инвестиционных предложений производителей железнодорожного состава при заключении долгосрочных договоров / Р.В. Мирошниченко // Сборник ВНИЖТ «Экономические проблемы развития железнодорожного транспорта на этапах его инновационных и структурных преобразований». - 2009. - С. 159-163.

8. Тиматков В.В. Особенности расчета стоимости жизненного цикла железнодорожной техники при рассмотрении ее отдельных узлов / В.В. Тиматков // Транспорт Российской Федерации. - 2010. - №2(27) - С. 54-55.

9. Методы оценки жизненного цикла подвижного состава железных дорог: монография / Э. Д. Тартаковский, С. Г. Грищенко, Ю. Е. Калабухин, А. П. Фалендыш. - Л.: Ноулидж, 2011. - 174 с.

10. Тартаковский Э.Д. Оценка жизненного цикла / Э.Д. Тартаковский, А.П. Фалендыш, Ю.Е. Калабухин, С. Г. Грищенко // Локомотив-информ. - 2013. №2(80). - C. 56-60. 